\title{
Assessment of Process Heating and Cooling Demand for Solar System Installation at Typical Industries in Ethiopia
}

\author{
Yacob G. Hiben ${ }^{1,2}$, Mulu B. Kahsay ${ }^{1}$, Johan Lauwart ${ }^{2}$ \\ ${ }^{1}$ Thermal and Energy Systems Chair, School of Mechanical and Industrial Engineering, Mekelle \\ University, Mekelle (Ethiopia) \\ ${ }^{2}$ Department of Electronics and Information Systems, Faculty of Engineering and Architecture, Ghent \\ University, Ghent-Zwijnaarde (Belgium)
}

\begin{abstract}
Several measures that bring about structural change in the economy of Ethiopia have been taken to achieve the overall goal of the industrial development strategy. However, the substantial share of fossil fuels and electricity requirement has been increased the burden on the trade balance of the imported petroleum volume and the Ethiopian power system. With this, considerable attention is being given for the energy that can be met alternatively using solar radiation which might be quite effective and economically competitive to the conventional systems as most regions in the country experience a more or less good intensity and uniform solar radiation. The development of an economically feasible and energy-efficient solar system requires validation through studies. Hence, the assessment of heating and cooling potential to identify the load profile which is non-existent mostly is necessary. Looking into the majority of solar industrial processes operating worldwide and the industrial sector development in Ethiopia, a survey has been made of two target industries (leather and soft drinks). The load profile results for the case studies at Sheba Leather Industry P.L.C. and MOHA Soft Drinks S.C showed a considerable demand for hot water at temperatures approximately equal to $35-55{ }^{\circ} \mathrm{C}$ and $60-85{ }^{\circ} \mathrm{C}$ respectively. The corresponding energy needed to heat the amount of water per day is estimated to be $10 \mathrm{GJ}$ and $54 \mathrm{GJ}$. There is also a significant cold water-glycol solution demand at a temperature approximately equal to $4{ }^{\circ} \mathrm{C}$ with a corresponding estimated daily cooling capacity of $21 \mathrm{GJ}$ in MOHA. These relevant results and the identified daily, weekly, and annual load profile will have significant importance for cost-effective energy substitution and conservation measures.
\end{abstract}

Keywords: Industrial process, Heating, Cooling, Demand, Ethiopia

\section{Introduction}

As a developing country, the overall goal of the industrial development strategy in Ethiopia is to bring about structural change in the economy. It is aimed at increasing the GDP share of the industry sector specifically increasing the share of the manufacturing sub-sector (MoI, 2017). With this objective, the government has taken several measures including establishing industrial zones, furnishing the industrial estates with necessary infrastructures (e.g. roads, power, telecommunication, and water), and organizing a responsible organ entrusted with the task of promoting and regulating this activity. The manufacturing sector is characterized by a high concentration of a limited range of light manufacturing activities such as leather, food and beverage, textile, nonmetallic, and furniture. The leather and food and beverage products with experienced reordered rankings have been on the top for the last 15 years. Moreover, policymakers have been doing their relentless efforts to promote these industries over the last decade. The industrial facilities are concentrated around the federal and regional capitals and primarily serve the domestic market (Gebreeyesus, 2013; Encyclopedia, 2013).

The industrial productions are supplied by different process streams which absorb heat (cold streams) and release heat (hot streams). Thermal and electrical energy are commonly utilized in the plants to supply the heating and cooling effects (Schweiger et al., 2015; Vannoni et al., 2008). At a global level, the use of fossil fuels is reported as the primary source of energy to meet industrial sector energy demand (Solomon, 1983). Likewise, the in-country electricity consumption was distributed as industrial (37\%), residential (37\%), and commercial (26\%). The volume of petroleum imports mainly used in the transport and industry sector has been growing rapidly ( $8 \%$ annually and higher) over the past ten years (Energypedia, 2013; FDRE, 2013). Thus, considerable attention is being given for the industrial processes that can be met alternatively using solar energy since most regions in the country experience a more or less uniform solar radiation ( 5 to $7 \mathrm{kWh} / \mathrm{m}^{2}$ for 5 to 8 hours) that might be quite effective and economically competitive with conventional heating and cooling systems ( UNEP, 2015; REEP, n.d.). 
Acceptance and dissemination of solar industrial process heating and cooling systems depend on their performance in industrial applications as the same directly affects their economic feasibility. Performance of the systems depend on several parameters such as available solar radiation, climatic conditions at the location of use, characteristics of solar collector used, and required process heating and cooling conditions (delivery temperatures, pressures, and mass flow rate, etc.) (von Storch et al., 2016; Mekhilef et al., 2011; Andersen and Furbo, 2009; Adsten et al., 2002; Rabl, 1981). It is, therefore, crucial to conduct a comprehensive feasibility study of solar energy for industrial processing. As such, quantifying the industrial heating and cooling demand within the plant under full operation is important. In short, the assessment is designed to determine where, when, why, and how heating and cooling is being used.

Many studies dealing with the performance assessment of solar industrial heating process (SIHP) systems have been reported in studies involving low temperature and intermediate temperature systems that could be easily provided by currently commercially available and marketed solar thermal technologies. The amount of thermal energy required in most of the industrial processes is below $250{ }^{\circ} \mathrm{C}$ (Ratismith et al., 2017; Ruud Kempener, 2014; ESTIF, 2006; Kalogirou, 2003). From the low-temperature systems, the effect of varying thermal energy demand due to different working patterns on the performance has been analyzed (Thabit and Stark, 1986). In this analysis, it was found that on clear sunny days, $95 \%$ of the thermal energy demand can be met with solar energy-based systems. For instance, the performance assessment details of a solar hot water generating system in an Australian food processing industry have been reported in the literature (Proctor and Morse, 1977). From the estimates obtained in the study, it was concluded that about $50 \%$ of the total heat demand of the industry that is required between 40 and $60{ }^{\circ} \mathrm{C}$ temperatures, could be supplied with available solar collector technologies. In another paper, a study for the application of non-concentrating collectors for the food industry in Germany is presented. In particular, the planning of four solar thermal systems producing process heat for a large and a small brewery, a malt factory, and a dairy are presented. In the breweries, the washing machines for returned bottles were chosen as a suitable process to be fed by solar energy; in the dairy, the spray-dryers for milk and whey powder production; and in the malt factory, the wither and kiln processes. Up to $400 \mathrm{kWh} / \mathrm{m}^{2}$ per annum were delivered from the solar collectors, depending on the type of collector (Kalogirou and Soteris, 2003). The use of solar energy to drive thermal powered cooling is also used as an alternative to the conventional systems. Most of the solar cooling systems are based on single-effect absorption chillers (which are more commercially developed). Flat-plate collectors or evacuated tube collectors are usually operated at temperatures around $85{ }^{\circ} \mathrm{C}$ to $95{ }^{\circ} \mathrm{C}$ for this purpose (Jaiswal et al., 2016; Allouhi et al., 2015; Lu et al., 2013; Luo et al., 2007; Luo et al., 2006).

Studies dealing with investigations of the economic viability of solar hot water and cooling systems have also reported. For instance, the system's economic viability for the soft drinks and vegetable oil industry in Khartoum (Sudan) was carried out (Ibrahim et al., 1990). The results presented that the solar energy systems have significant potential in industrial processes and substantial life-cycle savings can be achieved. In different case studies carried out in Greece (Karagiorgas et al., 2001), economic evaluation of SIHP systems with conventional fossil fuel-based systems have been made. In this analysis, eight successful applications of solar thermal systems have been identified. The outcomes of the study revealed that due to the increase in the price of liquid fuels, SIHP systems shall become cost-effective. Similarly, the case studies on the adoption of SIHP in the industries in Turkey and Pakistan confirmed the economic viability of SIHP for low temperature (60 to $80{ }^{\circ} \mathrm{C}$ ) requirements ( Muneer et al., 2006; Proctor and Morse, 1977). Abdulateef et al. (Abdulateef et al., 2011) also reported the economic performance of a non-concentrated solar-driven $\mathrm{NH}_{3}-\mathrm{H}_{2} \mathrm{O}$ absorption cooling system. As the collector area increases, the solar savings also increase until reaching the optimum collector area. But when the collector area is further increased, though the fuel savings continue to increase, the solar savings are decreased due to the excessive installation costs.

Looking into the majority of the projects on solar industrial process heat plants operating worldwide and the industrial sector development in Ethiopia, this paper investigates the potential in two target industries by case studies at Sheba Leather Industry (SLI) and MOHA Soft Drinks - Mekelle plant (MSD). The study data from these factories represents well the majority of the industries in the group. The study was made during regular operation of the factories and includes identifying: (i) current technologies and source of energy for heating and cooling, (ii) processes demanding hot and cold streams, (iii) working temperature and consumption level of the processes, and (iv) variability of the processes. The outputs of the study will have significant importance in terms of proper identification of daily, weekly, and annual load profiles useful for cost-effective implementation of the solar energy system thereby minimization of the uncertain conventional energy prices and environmental impacts. 


\section{Materials and Methods}

\subsection{Description of Target Industries}

Leather industries play an important role in processing a by-product or waste from the meat industry, namely the skins and hides into the leather in different mechanical and chemical processing steps such as tanning and retanning. The soft drinks industry processes sugar, carbonated water, and other flavors to form soda in different mechanical and chemical processing steps such as washing, sugar dissolving, mixing, and filling. These processes use a large quantity of water and energy in which the quantities vary depending on the specific processes operated, the equipment used, and management practices. The use of old and new technologies also leads to a wide variation in water and energy consumption.

Ethiopia's leather and soft drinks industry is witnessing rapid growth, as many domestic and multinational firms are being engaged in the production for domestic and global markets. There are around 30 tanneries processing skins and hides to different types of finished leather. The total wet-end installed capacity amounted to around 275 million square feet per year. Ethiopia's largest livestock population around 58 million cattle (the largest in Africa and $6^{\text {th }}$ in the world), 29 million sheep ( $3^{\text {rd }}$ in Africa and $10^{\text {th }}$ in the world), and 30 million goats ( $3^{\text {rd }}$ in Africa and $8^{\text {th }}$ in the world) also represents a largely untapped market. The Ethiopian beverages industry profiles 16 companies including the eight operating units under MOHA which dominates Ethiopia's multi-million dollar carbonated soft drinks market, with a market share of approximately $52 \%$. A population of more than 100 million people also represents a largely untapped consumer market and growing demand for carbonated soft drinks.

In this paper, the typical leather and soft drinks factories in Northern Ethiopia, Tigray region are assessed for the case studies. SLI is located at Wukro city $822 \mathrm{~km}$ and MSD is located at Mekelle city $780 \mathrm{~km}$ far from the capital Addis Ababa. In SLI, wet-blue processing involves the processing of raw skins and hides into a product called Crust, a stable product that cannot rot and is an internationally traded commodity. The production line in MSD is designed to bottle the processed soda in 330 milliliters bottles in the form of Pepsi-Cola, Miranda, and 7Up.

\subsection{Description of Target Utilities}

Currently, a considerable amount of fuel, electricity, and water are utilized every year by the utilities and processing units for heating and cooling purposes. The industrial processing units use boilers to produce steam (the vaporized state of water). This contains heat energy and transfers that energy into a variety of processes in the industries. Similarly, chillers are used to produce cold which absorbs energy from a variety of hot stream processes. The general production and distribution flow of steam and cold media is shown in Figure 1.

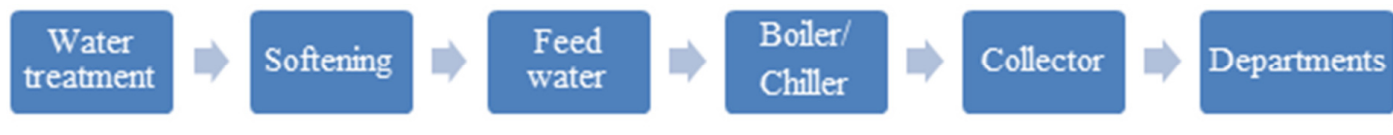

Fig. 1: General production and distribution flow of steam and cold media

The boiler in SLI and MSD is essentially a cylindrical shape closed vessel inside which water is stored. Basic parts of the boiler are burner, combustion chamber, and heat exchanger. The fuel is stored in fuel tanks. The pressurized fuel is burnt in a furnace and hot gases are produced. These hot gases come in contact with water vessels to transfer their heat to the water and consequently, steam is produced in the boiler. Accumulator or steam head is used for distributing steam that is produced in the boiler to the sections in which the pressure is reduced. Some steam/water is lost through leakages and other losses, so the water recycled into the boiler feed tanks or economizer after steam has been condensed is less in amount and this requires adding more make-up water at a specific interval. Steam flash from the boiler is used to pre-heat the condensate and make-up water in the feed water tank before it is fed into the boilers for reducing fuel consumption. For that matter, solar water heaters to pre-heat the make-up water and condensate return is identified as one option to reduce steam flash and fuel needed.

The refrigeration cycle in MSD chiller starts with a low-temperature and low-pressure $\left({ }^{0} \mathrm{C}, 3.5 \mathrm{bar}\right)$ gas, ammonia $\left(\mathrm{NH}_{3}\right)$ as a refrigerant entering the compressor $(45 \mathrm{~kW})$ where it is compressed to high-temperature and highpressure gas $\left(36{ }^{\circ} \mathrm{C}, 13 \mathrm{bar}\right)$ entering the condenser to reject heat. In the evaporator, heat from the process waterglycol solution boils the refrigerant, which changes it from a high-pressure gas to a low-pressure gas and chills the water-glycol solution supplied to the processes. This cold fluid removes heat from the processes and the warm fluid returns to the chiller. For that matter, one option to reduce compressor power needed would be to use solar water heaters for absorption type refrigeration. 


\subsection{Description of Target Processes}

The heating and cooling processes of the industries are represented by a high share of heat demand in the low to medium temperature range and cooling capacity. In SLI, typical process hot water consumption during production includes tanning and re-tanning of skins and hides. In MSD, typical process hot water and cold water-glycol solution consumption during production include case washing, bottle washing, syrup preparation, and cleaning in the place (CIP).

The wet-blue processed in SLI use hot water and chemicals in two steps. In these stages, hot water is prepared in separate tanks in two ways (1) using the steam condensates from the drying processes in the finishing section for the skin line and (2) using dry steam from the boiler using plate type heat exchanger for the hide line. Finally, hot water is supplied to the tanning and re-tanning drums at the required amount and temperatures. The skin process has two functional drums (3, 000 Liters each) for tanning and five drums (900 Liters each and 2, 000 Liters each) for two stages re-tanning. The hide process has three functional drums (3,500 Liters each) for tanning and four drums (900 Liters each and 1, 500 Liters each) for two stages re-tanning.

The case and bottle washers use make-up water, steam, and caustic soda to wash the cases and bottles. The washer's nominal performance is mainly dependent on the carbonate content of the caustic. The create washer has once chamber for soaking. The bottle washer has one pre-wash section, two chambers for soaking with different concentrations, and three rinsing sections. These steps are done in the washing machine which consists of a series of tanks and sprays nozzles. There is no direct contact of steam and the bottles in the washing process, except that heat is passed through tube type heat exchanger made of stainless steel in three tanks. When the steam loses heat to the water, it condenses and goes back to the boiler feed water tank or economizer through a return pipe. The freshwater consumption to the sections is on average $12 \mathrm{~m}^{3} / \mathrm{hr}$.

Sugar is dissolved for the preparation of simple syrup (a mixture of hot water and sugar). The sugar dissolver has a motor mounted on it that drives the agitator, to ensure uniform distribution of heat. The water $(3,200$ Liters per batch) is heated by steam passing through a steam jacket in between the walls of the cylinder. When the steam loses heat to the water, it condenses and is let out of the steam jacket through a pipe at the lower end of the cylinder. The condensate from the sugar dissolver goes back to the boiler feedwater tank or economizer. Sugar is poured in the heated water, to ensure the sugar dissolves the mixture is allowed to wait for some time. Once the mixture (simple syrup) is prepared, it is cooled while flowing to the final syrup tank in the double heat exchanger. The first step is to exchange heat with cold water from a cooling tower and the second step is to exchange heat with cold water-glycol solution from the chiller. A pumping system $\left(17 \mathrm{~m}^{3} / \mathrm{hr}\right)$ circulates the water-glycol solution from the chiller to the process.

The syrup can be referred to as final syrup when it is at the prescribed volume for the final batch size prepared after adding the beverage base ingredients and topping up with the treated water. This final syrup is ready in the blending tanks for use in the filling and bottling line, provided that it passed all the required quality control tests. Once the mixture (Soda) is prepared in the mixer, it is also cooled while flowing to the filler using a cold waterglycol solution from the chiller. A pumping system $\left(35 \mathrm{~m}^{3} / \mathrm{hr}\right)$ circulates the water-glycol solution from the chiller to the process.

The CIP tanks (10, 000 Liters hot caustic and 10, 000 Liters hot water) is used for cleaning the pipes and the tanks in the manufacturing processes. The water used in CIP is heated using steam and a heat exchanger. The hot water is circulated in the tank according to the changeover matrix for 3-step and 5-step cleaning.

\subsection{Data Collection and Processing}

Data collection was made within the scope from the identified utilities and processes for the hot and cold streams. Primary data was collected through field visits and measurements in the utilities and processes within the factories. Secondary data was collected from existing recorded data, monthly utility bills, and invoices for delivered energy and fuel, process manual, machine catalog, and literature. The collected data are analyzed to get energy demand and load profiles. A spreadsheet was used to create a database and analyze data.

A detailed material and heat balance with their corresponding assumptions were conducted to evaluate missed data using (1) and (2) (Amiri, 2012):

$m_{\text {in }}=m_{\text {out }}$ or $\rho v_{\text {in }}=\rho v_{\text {out }}$

$Q_{\text {net }}=m_{1} C_{p}\left(\Delta T_{1}\right)-m_{2} C_{p}\left(\Delta T_{2}\right)=m_{1}\left(\Delta h_{1}\right)-m_{2}\left(\Delta h_{2}\right)$

Primary energy consumption is estimated from equation (3): 
Energy Demand $=\frac{\rho v C_{p}\left(T_{\text {set } p t}-T_{\text {supply }}\right)}{\eta}$

Fluid properties can be found from property tables or the property equations in Table 1.

Tab. 1: Property equations for liquid water (273.2 K - 600 K) and atmospheric pressure (Zografos et al., 1987)

\begin{tabular}{cl}
\hline Equation & Dimension \\
\hline$\rho=-3.0115 * 10^{-6} T_{a v}{ }^{3}+9.6272 * 10^{-4} T_{a v}{ }^{2}-0.11052 T_{a v}+1022.4$ & $\mathrm{kgm}^{-3}$ \\
$C_{p}=1.7850 * 10^{-7} T_{a v}{ }^{3}-1.9149 * 10^{-4} T_{a v}{ }^{2}+6.7953 * 10^{-2} T_{a v}-3.7559$ & $\mathrm{kJkg}^{-1} \mathrm{~K}^{-1}$ \\
\hline
\end{tabular}

Where $\mathrm{m}$ is fluid mass flow, $\rho$ is the fluid density, $\mathrm{v}$ is fluid volume, $\mathrm{C}_{\mathrm{P}}$ is fluid specific heat, $\mathrm{T}$ is fluid temperature, $\mathrm{h}$ is fluid enthalpy, and $\eta$ is efficiency.

For continuous processes, hourly basis data were separated according to each hour average production and consumption of the processes obtained from equation (4):

consumption per hour $=$ production per hour $*$ consumption per product

consumption per hour $=\frac{\text { daily consumption }}{\text { daily processing time in hour }}$

For non-continuous (batch) processes, hourly basis data were separated according to an estimated demand of the processes and the schedule which lasts obtained from equation (5):

consumption per hour $=\frac{\text { consumption per batch }}{\text { process time schedule in hour }}$, process time schedule $<1$

consumption per hour $=$ consumption per batch, process time schedule $\geq 1$ and first hour

consumption per hour $=0$, process time schedule $\geq 1$ and not the first hour

\section{Results and Discussion}

3.1. Capacity and Availability

The capacity and availability of the factories and processes are summarized in Table 2 .

Tab. 2: Capacity and availability of the factories and processes

\begin{tabular}{|c|c|c|}
\hline Description & SLI & MSD \\
\hline Production capacity & $\begin{array}{l}\rightarrow 6,000 \text { pcs of skin/day } \\
\rightarrow 600 \text { pcs of hides/day }\end{array}$ & $\rightarrow 36,000$ bottles $/ \mathrm{h}$ \\
\hline Running time & $\begin{aligned} \rightarrow & 16 \mathrm{~h} / \text { day in two shifts from } 6: 00 \mathrm{am} \\
& \text { to } 10: 00 \mathrm{pm} . \\
\rightarrow & \text { Alternate } 6 \text { and } 5 \text { days a week. } \\
\rightarrow & \text { No work during holidays and } \\
& \text { machine unavailability. }\end{aligned}$ & $\begin{aligned} \rightarrow & 16 \mathrm{~h} / \text { day in two shifts from 6:00 am } \\
& \text { to } 10: 00 \mathrm{pm} . \\
\rightarrow & 6 \text { days a week. } \\
\rightarrow & \text { No work during holidays, machine } \\
& \text { unavailability, annual planned } \\
& \text { maintenance. }\end{aligned}$ \\
\hline Availability & $\rightarrow 95.84 \%$ & $\rightarrow 82.6 \%$ \\
\hline $\begin{array}{l}\text { Actual annual } \\
\text { processing }\end{array}$ & $\begin{array}{l}\rightarrow 98,691.3 \mathrm{~m}^{2} \text { Skin } \\
\rightarrow 223,026.6 \mathrm{~m}^{2} \text { Hide }\end{array}$ & $\rightarrow 101$ million bottles \\
\hline
\end{tabular}

3.2. Heating and Cooling Utilities and Consumptions

Essential data on the base heating and cooling utilities can be seen in Table 3.

Tab. 3: Heating and cooling utilities technical and operations data

\begin{tabular}{llll}
\hline Industry & SLI & & MSD \\
\hline Type & Brox Boiler & MINGAZZNI Boiler & HANSA Chiller \\
Model & SYK100 & CEI EN 60439-1 & TIWK AP 2 V300 1180 \\
Energy source & Furnace oil & Diesel Fuel & Electricity \\
Heating value & $44 \mathrm{MJ} / \mathrm{kg}$ & $45 \mathrm{MJ} / \mathrm{kg}$ & -
\end{tabular}




\begin{tabular}{|c|c|c|c|}
\hline Sp. gravity & $0.95 \mathrm{~kg} / \mathrm{l}$ & $0.86 \mathrm{~kg} / \mathrm{l}$ & - \\
\hline Cost & 16.55 Birr/l & 18.30 Birr/l & - \\
\hline Material out & Steam & Steam & Cold water-glycol solution \\
\hline Material in & Feedwater & Feedwater & Hot water-glycol solution \\
\hline Capacity & $4000 \mathrm{~kg} / \mathrm{hr}$ & $350-4000 \mathrm{~kg} / \mathrm{hr}$ & $393 \mathrm{~kW}, 55 \mathrm{~m}^{3} / \mathrm{hr}$ \\
\hline $\mathbf{T}_{\text {out }}, \mathbf{P}_{\text {out }}$ & $100-195{ }^{0} \mathrm{C}, 1-10 \mathrm{bar}$ & $100-190{ }^{\circ} \mathrm{C}, 5-11 \mathrm{bar}$ & $4{ }^{0} \mathrm{C}, 1.5$ bar \\
\hline $\mathbf{T}_{\text {in }}, \mathbf{P}_{\text {in }}$ & $75-85{ }^{0} \mathrm{C}, 1-7$ bar & $80-85{ }^{0} \mathrm{C}, 5-7$ bar & $11{ }^{0} \mathrm{C}, 1.5 \mathrm{bar}$ \\
\hline Efficiency & $83 \%$ & $84 \%$ & $4.4 \mathrm{COP}$ \\
\hline Operation schedule & $\begin{array}{l}\text { 7:00 am - 6:00 pm (11 } \\
\text { hrs/day) }\end{array}$ & $\begin{array}{l}\text { 7:00 am - 9:00 pm (15 } \\
\text { hrs/day) }\end{array}$ & $\begin{array}{l}\text { 7:00 am - 8:00 pm (14 } \\
\text { hrs/day) }\end{array}$ \\
\hline Variability & $\begin{array}{l}\text { Continuous with variable } \\
\text { load }\end{array}$ & $\begin{array}{l}\text { Continuous with variable } \\
\text { load }\end{array}$ & $\begin{array}{l}\text { Continuous with variable } \\
\text { load }\end{array}$ \\
\hline $\begin{array}{l}\text { Output energy } \\
\text { consumption }\end{array}$ & $0.029 \mathrm{l} / \mathrm{kg}$ & $0.02351 / \mathrm{kg}$ & $0.029 \mathrm{~kJ} / \mathrm{m}^{3}$ \\
\hline $\begin{array}{l}\text { Production output } \\
\text { consumption }\end{array}$ & $2264 \mathrm{~kg} / \mathrm{hr}$ & $2929.26 \mathrm{~kg} / \mathrm{hr}$ & $47.14 \mathrm{~m}^{3} / \mathrm{hr}$ \\
\hline Production loss & $2 \%$ & $2 \%$ & - \\
\hline $\begin{array}{l}\text { Production energy } \\
\text { consumption }\end{array}$ & $0.35 \mathrm{l} / \mathrm{m}^{2}$ & 0.0042 1/bottle & $0.0014 \mathrm{~kJ} / \mathrm{bottle}$ \\
\hline $\begin{array}{l}\text { Production energy } \\
\text { cost }\end{array}$ & 5.77 Birr/m² & 0.076 Birr/bottle & $0.023 \mathrm{Birr} / \mathrm{bottle}$ \\
\hline
\end{tabular}

\subsection{Processes Heating and Cooling Profiles}

Most of the processes heating and cooling systems are indirect heating using heat exchangers and cooling coils except the direct heating by the steam flash for the feed water and use of condensate return for SLI skin processing. The heat exchangers have approximately an effectiveness of 0.9 . The supply temperatures of make-up and recycled or condensate water are between $22-24{ }^{\circ} \mathrm{C}$ and $70-80{ }^{\circ} \mathrm{C}$ respectively. The water-glycol solution is supplied at $11{ }^{\circ} \mathrm{C}$. Each process has specific requirements such as water quantity, setpoint temperature, and period of usage. Table 4 provides brief information regarding the processes unit operations considered.

Tab. 4: Working conditions for each industrial process

\begin{tabular}{|c|c|c|c|c|c|}
\hline \multirow[b]{2}{*}{ Industry } & \multirow[b]{2}{*}{ Unit operation } & \multicolumn{4}{|c|}{ Load profile } \\
\hline & & $\begin{array}{l}\text { Daily water } \\
\text { supply }\left(\mathbf{m}^{3}\right)\end{array}$ & $\begin{array}{c}\text { Setpoint } \\
\text { Temp. } \\
\left({ }^{0} \mathrm{C}\right)\end{array}$ & Period (hrs) & $\begin{array}{c}\text { Energy } \\
\text { Demand } \\
\text { (GJ) }\end{array}$ \\
\hline \multirow{8}{*}{ SLI } & Skin tanning & 24 & 35 & $4(1 \mathrm{pm}-5 \mathrm{pm})$ & 1.48 \\
\hline & \multirow{2}{*}{ Skin re-tanning } & 22.50 & 40 & $4(7 \mathrm{am}-10 \mathrm{am}, 4 \mathrm{pm}-5 \mathrm{pm})$ & 2.02 \\
\hline & & 10 & 50 & $1(11 \mathrm{am}-12 \mathrm{am})$ & 1.46 \\
\hline & Hide tanning & 21 & 40 & $2(1 \mathrm{pm}-3 \mathrm{pm})$ & 1.88 \\
\hline & \multirow{2}{*}{ Hide re-tanning } & 18 & 45 & $4(7 \mathrm{am}-10 \mathrm{am}, 4 \mathrm{pm}-5 \mathrm{pm})$ & 2.12 \\
\hline & & 6 & 55 & $1(11 \mathrm{am}-12 \mathrm{am})$ & 1.04 \\
\hline & Feedwater pre-heating & 15 & 80 & $11(7 \mathrm{am}-6 \mathrm{pm})$ & 4.70 \\
\hline & (Make-up, Condensate) & 10 & 80 & $11(7 \mathrm{am}-6 \mathrm{pm})$ & 3.24 \\
\hline \multirow{9}{*}{ MSD } & Create washing & 70 & 40 & $12(7 \mathrm{am}-7 \mathrm{pm})$ & 6.28 \\
\hline & Bottle soaking 1 & 68 & 75 & $12(7 \mathrm{am}-7 \mathrm{pm})$ & 2.01 \\
\hline & Bottle soaking 2 & 68 & 80 & $12(7 \mathrm{am}-7 \mathrm{pm})$ & 19.36 \\
\hline & Bottle hot water tank & 10 & 60 & $12(7 \mathrm{am}-7 \mathrm{pm})$ & 21.24 \\
\hline & Sugar dissolving & 9.6 & 80 & $\begin{array}{l}3(7 \mathrm{am}-8 \mathrm{am}, 11 \mathrm{am}-12 \mathrm{pm}, \\
4 \mathrm{pm}-5 \mathrm{pm})\end{array}$ & 2.99 \\
\hline & CIP & 20 & 85 & $1(8 \mathrm{pm}-9 \mathrm{pm})$ & 2.21 \\
\hline & \multirow{2}{*}{$\begin{array}{l}\text { Feedwater pre-heating } \\
\text { (Make-up, Condensate) }\end{array}$} & 0.83 & 85 & $14(7 \mathrm{am}-9 \mathrm{pm})$ & 0.28 \\
\hline & & 41.33 & 85 & $14(7 \mathrm{am}-9 \mathrm{pm})$ & 3.41 \\
\hline & Water-glycol cooling & 650 & 4 & $12(7 \mathrm{am}-7 \mathrm{pm})$ & 21.1 \\
\hline
\end{tabular}

The volume of water needed for each process has been determined using the manufacturing characteristics and the recognized standards. The approximate hot water consumption for each factory was: (a) SLI processes, 101.5 $\mathrm{m}^{3} /$ day; (b) MSD processes, $245.6 \mathrm{~m}^{3} /$ day; (c) SLI feedwater, $25.3 \mathrm{~m}^{3} /$ day; and (d) MSD feedwater, $42.2 \mathrm{~m}^{3} /$ day. 
The approximate cold water-glycol solution consumption for SMD was $522 \mathrm{~m}^{3} / \mathrm{day}$. The energy needed to heat the amount of water per day is estimated: (a) SLI processes, $10 \mathrm{GJ}$; (b) MSD processes, $54.1 \mathrm{GJ}$; (c) SLI feedwater, $7.94 \mathrm{GJ}$; and (d) MSD feedwater, 3.69 GJ. The approximate daily cooling capacity is estimated at 21.1 GJ. A quasi-repeated hourly load profile for the working days and weeks in a year is illustrated in Figure.2.
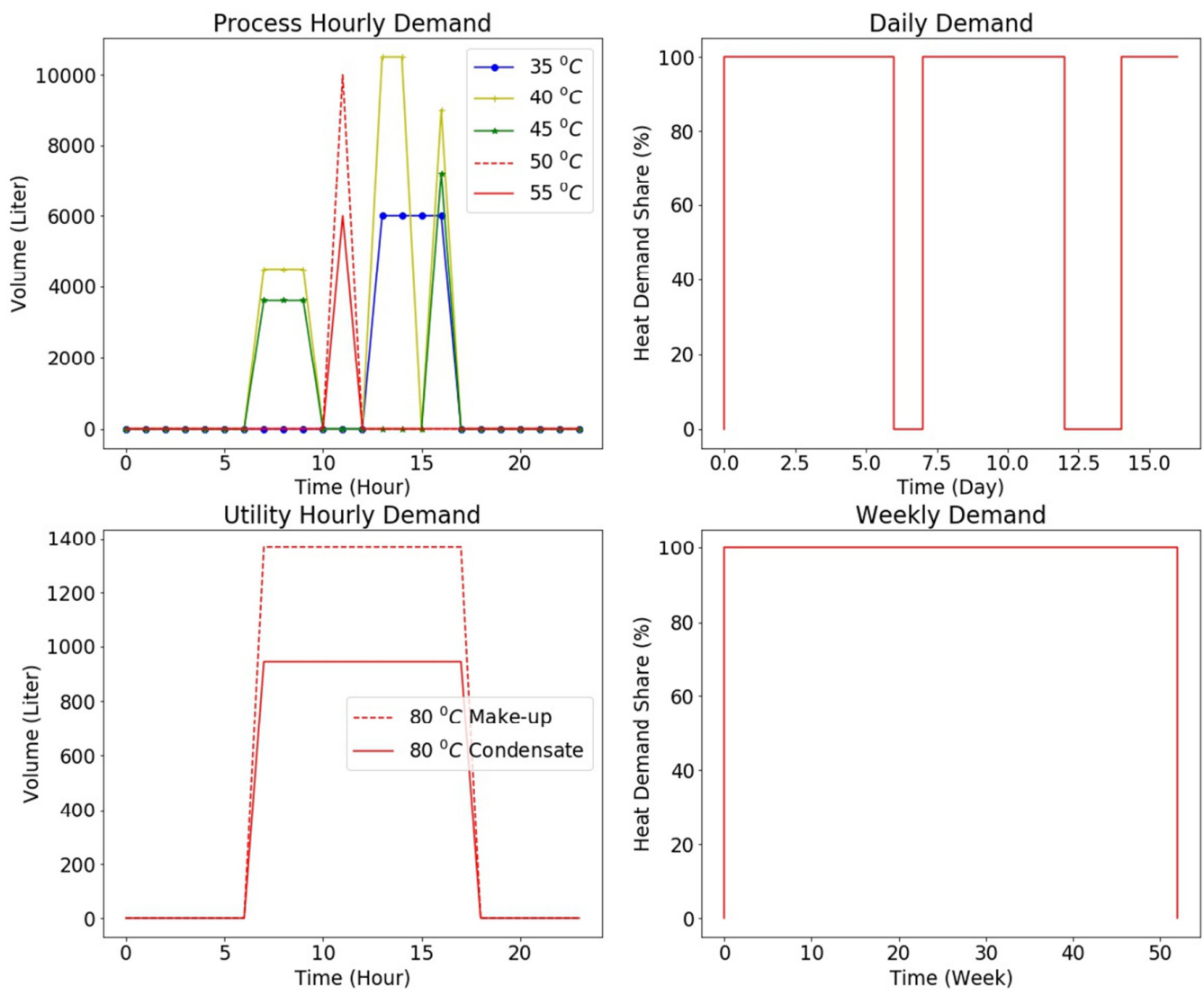

(a) 

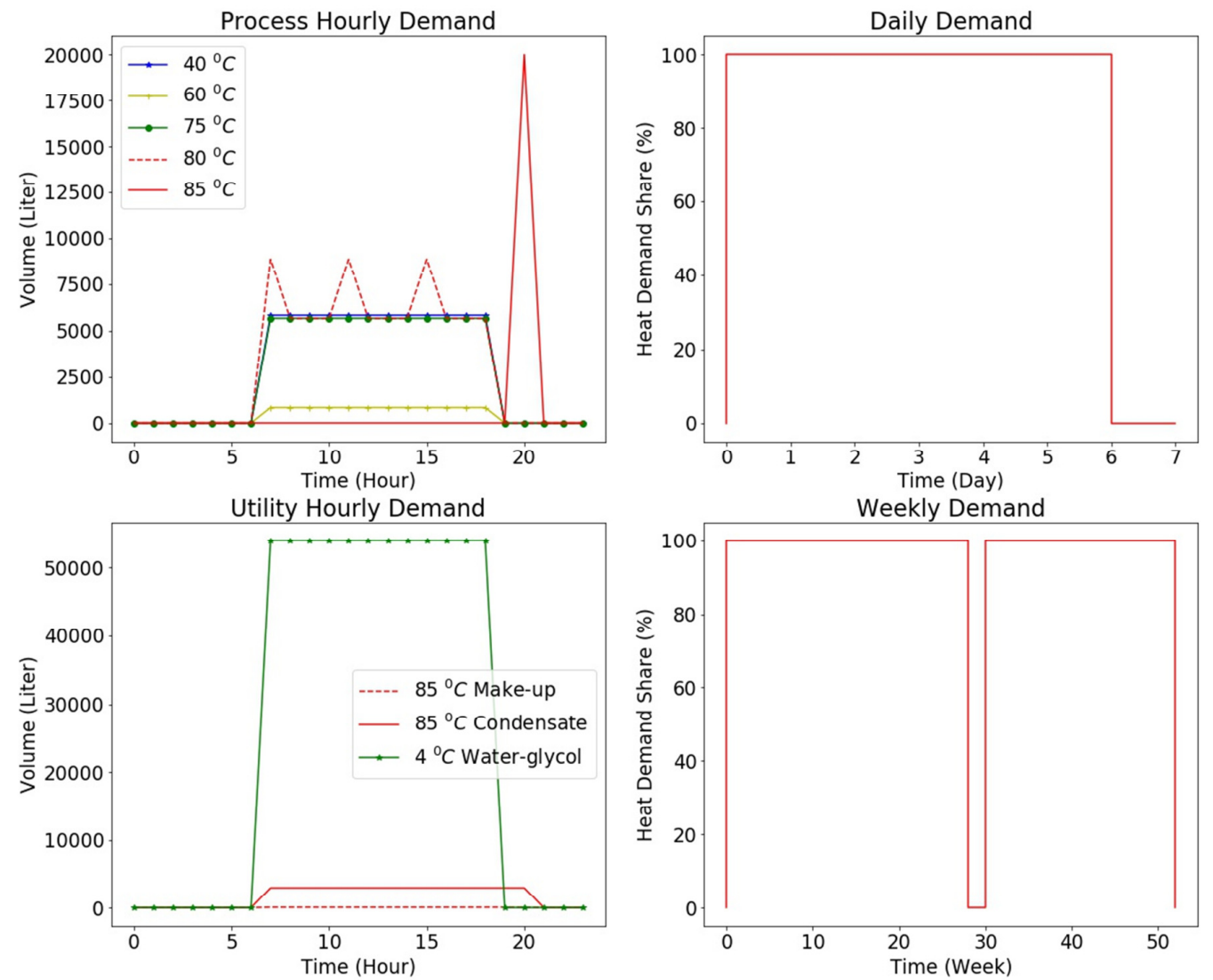

(b)

Fig. 2: Load profiles (a) Processes and feedwater heating in SLI, (b) Processes, feedwater heating, and water-glycol cooling in MSD

This proper identification of daily consumption was one of the objectives of the study and it is important information for system sizing. All the factories mainly process their products during the day time as shown in Figure 2 ( $\mathrm{a}$ and $\mathrm{b}$ ). During the night there is no hot water demand since the companies are only working from 6:00 am to 10:00 pm (two shifts). In SLI, there is no demand for alternate one or two days at weekends (Figure 2a). In MSD, there is no demand at weekends and during the 29 and 30 weeks of a year (Figure 2b).

Figure 2 illustrates the hourly hot water demands averaged during the days for SLI and MSD. As shown in Figure $2 \mathrm{a}$, the demand at the leather factory is intermittent at some interval of hours. It indicates that the peak demand reaching 10, 000 liters per hour at a temperature of $40{ }^{\circ} \mathrm{C}$ is around noon, which is an advantage for storage size reduction of solar energy application. Figure $2 \mathrm{~b}$ shows the demand at the soft drinks factory is nearly uniform with batch processes for sugar dissolving and CIP at some interval of hours. Large hot water consumption reaching 5,000 liters per hour at a temperature of $80{ }^{\circ} \mathrm{C}$ is continuously required during the day. The peak demand reaching 20, 000 liters per hour at a temperature of $85{ }^{\circ} \mathrm{C}$ is mostly around evening when all the production equipment is cleaned before closing time. Similarly, uniform consumption during working hours is shown in Figure 2 (a and b) to pre-heat feedwater and cool the water-glycol solution.

\section{Conclusion}

The heating and cooling potential assessment in SLI and MSD were conducted to quantify the requirements of the processes for identifying potential intervention areas for solar thermal integration. Based on the assessment performed, SLI works in two shifts with alternate five or six days a week all over the year and SMD works in two shifts with six days a week all over the year except for two weeks planned maintenance period. Discontinuous (batch) load profiles of the hot water demand for tanning and re-tanning processes in SLI as well as sugar dissolving and cleaning of production equipment in MSD are identified. During working hours, there is a high demand for hot water around noon in SLI and in MSD, though there is always a certain demand for cleaning water, there is a very high demand mostly when all the production equipment is cleaned before closing time. Besides, the continuous load profile of the washing processes is being part of the production in MSD. Constant boiler feedwater 
heating as well as water-glycol solution cooling are also identified as energy-intensive processes for possible solar thermal integration. Such a reliable knowledge of the process parameters (mass flows, temperature levels, load profile, etc.) are pre-conditions to plan and design a reliable and economical solar thermal system.

\section{Acknowledgments}

The authors would like to acknowledge CoE in REWiSE project for the funds to the Ph.D. study leading to this article.

\section{References}

Abdulateef, J., Alghoul, M., Zaharim, A., Sopian, K. Bin, 2011. Economic analysis of combined solar-assisted ejector absorption refrigeration system.

Adsten, M., Perers, B., Wäckelgård, E., 2002. The influence of climate and location on collector performance. Renewable Energy 25, 499-509. https://doi.org/10.1016/S0960-1481(01)00091-X

Allouhi, A., Kousksou, T., Jamil, A., Bruel, P., Mourad, Y., Zeraouli, Y., 2015. Solar driven cooling systems: An updated review. Renewable and Sustainable Energy Reviews. https://doi.org/10.1016/j.rser.2014.12.014

Amiri, M., 2012. Fundamentals of Thermodynamics, in: Introduction to Thermodynamics of Mechanical Fatigue. pp. 11-27. https://doi.org/10.1201/b12725-3

Andersen, E., Furbo, S., 2009. Theoretical variations of the thermal performance of different solar collectors and solar combi systems as function of the varying yearly weather conditions in Denmark. Solar Energy 83, 552565. https://doi.org/10.1016/j.solener.2008.10.009

Encyclopedia, 2013. Industry - Ethiopia - future, sector [WWW Document]. URL https://www.nationsencyclopedia.com/Africa/Ethiopia-INDUSTRY.html (accessed 4.9.19).

Energypedia, 2013. Ethiopia Energy Situation - energypedia.info [WWW Document]. URL https://energypedia.info/wiki/Ethiopia_Energy_Situation (accessed 4.8.19).

ESTIF, 2006. European Solar Thermal Industry Federation [WWW Document]. URL http://www.estif.org/fileadmin/estif/content/policies/downloads/D23-solar-industrial-process-heat.pdf (accessed 3.18.19).

FDRE, F.D.R. of E.M. of W.I. and E., 2013. Updated Rapid Assessment and Gap Analysis on Sustainable Energy for All [WWW Document]. africa.org/fileadmin/uploads/se4all/Documents/Country_RAGAs/MWH_-_UpdatedRapid_Gap_Analysis.pdf (accessed 4.8.19).

Gebreeyesus, M., 2013. Industrial Policy and Development in Ethiopia: Evolution and Current Performance. WIDER Working Paper.

Ibrahim, O.M., Ghoneim, A.A., Halabi, O.A., Kamil, A., 1990. Solar industrial process heat potential in Khartoum, Sudan. Solar \& Wind Technology 7, 649-654. https://doi.org/10.1016/0741-983X(90)90039-5

Jaiswal, A.K., Mitra, S., Dutta, P., Srinivasan, K., Srinivasa Murthy, S., 2016. Influence of cycle time and collector area on solar driven adsorption chillers. Solar Energy 136, 450-459. https://doi.org/10.1016/j.solener.2016.07.023

Kalogirou, S., 2003. The potential of solar industrial process heat applications. Applied Energy 76, 337-361. https://doi.org/10.1016/S0306-2619(02)00176-9

Kalogirou, Soteris, 2003. The potential of solar industrial process heat applications. Applied Energy 76, 337-361.

Karagiorgas, M., Botzios, A., Tsoutsos, T., 2001. Industrial solar thermal applications in Greece: Economic evaluation, quality requirements and case studies. Renewable and Sustainable Energy Reviews 5, 157-173. https://doi.org/10.1016/S1364-0321(00)00012-5

Lu, Z.S., Wang, R.Z., Xia, Z.Z., Lu, X.R., Yang, C.B., Ma, Y.C., Ma, G.B., 2013. Study of a novel solar adsorption cooling system and a solar absorption cooling system with new CPC collectors. Renewable Energy 50, 299 306. https://doi.org/10.1016/J.RENENE.2012.07.001

Luo, H.L., Dai, Y.J., Wang, R.Z., Wu, J.Y., Xu, Y.X., Shen, J.M., 2006. Experimental investigation of a solar adsorption chiller used for grain depot cooling. Applied Thermal Engineering 26, 1218-1225. https://doi.org/10.1016/J.APPLTHERMALENG.2005.10.036

Luo, H.L., Wang, R.Z., Dai, Y.J., Wu, J.Y., Shen, J.M., Zhang, B.B., 2007. An efficient solar-powered adsorption chiller and its application in low-temperature grain storage. Solar Energy 81, 607-613. 
https://doi.org/10.1016/J.SOLENER.2006.09.001

Mekhilef, S., Saidur, R., Safari, A., 2011. A review on solar energy use in industries. Renewable and Sustainable Energy Reviews. https://doi.org/10.1016/j.rser.2010.12.018

MoI, 2017. Investment Opportunity in Manufacturing Industry Investment Research, Monitoring and Support Directorate 1-34.

Muneer, T., Maubleu, S., Asif, M., 2006. Prospects of solar water heating for textile industry in Pakistan. Renewable and Sustainable Energy Reviews 10, 1-23. https://doi.org/10.1016/J.RSER.2004.07.003

Proctor, D., Morse, R.N., 1977. Solar energy for the Australian food processing industry. Solar Energy 19, 63-72. https://doi.org/10.1016/0038-092X(77)90089-5

Rabl, A., 1981. Yearly average performance of the principal solar collector types. Solar Energy 27, $215-233$. https://doi.org/10.1016/0038-092X(81)90123-7

Ratismith, W., Favre, Y., Canaff, M., Briggs, J., 2017. A non-tracking concentrating collector for solar thermal applications. Applied Energy 200, 39-46. https://doi.org/10.1016/j.apenergy.2017.05.044

REEP, n.d. Ethiopia Infrastructure, Power \&amp; Energy Investment Summit 2014 I REEEP [WWW Document]. URL https://www.reep.org/events/ethiopia-infrastructure-power-energy-investment-summit-2014 (accessed 4.8.19).

Ruud Kempener, 2014. IEA-ETSAP and IRENA Solar Heat for Industrial Processes ENERGY TECHNOLOGY SYSTEMS ANALYSIS PROGRAMME.

Schweiger, H., Mendes, J.F., Carvalho, M.J., Hennecke, K., Krüger, D., 2015. Solar heat for industrial processes, in: Advances in Solar Energy: An Annual Review of Research and Development in Renewable Energy Technologies. pp. 216-260. https://doi.org/10.4324/9781315793221-14

Solomon, J., 1983. PROCESS HEATING. Chemical Engineer (London) 24-26.

Thabit, S.S., Stark, J., 1986. Effects of working patterns on solar generated heat in UK industry. Applied Energy 22, 165-186. https://doi.org/10.1016/0306-2619(86)90001-2

UNEP, 2015. Etiopia: Energy profile, Total energy production,Total energy consumption and Production.

Vannoni, C., Battisti, R., Drigo, S., 2008. Task 33/IV-Potential for Solar Heat in Industrial Processes Potential for Solar Heat in Industrial Processes Task 33/IV-Potential for Solar Heat in Industrial Processes.

von Storch, H., Roeb, M., Stadler, H., Sattler, C., Bardow, A., Hoffschmidt, B., 2016. On the assessment of renewable industrial processes: Case study for solar co-production of methanol and power. Applied Energy 183, 121-132. https://doi.org/10.1016/j.apenergy.2016.08.141

Zografos, A.I., Martin, W.A., Sunderland, J.E., 1987. Equations of properties as a function of temperature for seven fluids. Computer Methods in Applied Mechanics and Engineering 61, 177-187. https://doi.org/10.1016/0045-7825(87)90003-X 